\title{
Aggregatibacter aphrophilus, Penicillinase Positive
}

National Cancer Institute

\section{Source}

National Cancer Institute. Aggregatibacter aphrophilus, Penicillinase Positive. NCI

Thesaurus. Code C119318.

Any bacterial species identified as Aggreg atibacter aphrophilus that produces the enzyme penicillinase. 